\title{
Melanocytic Skin Tumors: Does the Molecular Progression Model Fit With the Routine Clinicopathological Practice?
}

\author{
Gerardo Ferrara, ${ }^{1}$ Mirna Bradamante ${ }^{2}$
}

1 Anatomic Pathology Unit, Macerata General Hospital, Macerata, Italy

2 Department of Dermatology and Venereology, University Hospital Centre Zagreb, Croatia

Key words: nevus, melanocytoma, melanoma, histopathology, molecular genetics

Citation: Ferrara G, Bradamante M. Melanocytic skin tumors: does the molecular progression model fit with the routine clinicopathological practice? Dermatol Pract Concept. 2020;10(1):e2020001. DOI: https://doi.org/10.5826/ dpc.1001a01

Accepted: September 9, 2019; Published: December 31, 2019

Copyright: @2019 Ferrara and Bradamante. This is an open-access article distributed under the terms of the Creative Commons Attribution License, which permits unrestricted use, distribution, and reproduction in any medium, provided the original author and source are credited.

Funding: None.

Competing interests: The authors have no conflicts of interest to disclose.

Authorship: Both authors have contributed significantly to this publication.

Corresponding author: Gerardo Ferrara, MD, Anatomic Pathology Unit, Macerata General Hospital, Via Santa Lucia 2, I-62100 Macerata, Italy. Email: gerardo.ferrara@libero.it

The definition of a spectrum of melanocytic tumors, with superficial atypical proliferations (high-grade dysplastic nevus and melanoma in situ) and mass-forming (tumorigenic) neoplasms (melanocytomas) considered as an intermediate molecular progression stage in melanomagenesis, has been recently set forth by the WHO Working Group [1]. The existence of a molecular spectrum involves progressive accumulation of genetic abnormalities which, in turn, implies an increasing risk of unfavorable biological behavior. It is thus supposed that:

1. Benign nevi harbor a single driver mutation (involving $N R A S$ in congenital nevi, BRAF in acquired nevi, HRAS in a few Spitz nevi, GNAQ or GNA11 in blue nevi) or translocation (kinase fusion of $A L K, B R A F, R O S 1$, NTRK1, NTRK3, MET, RET, MAP3K3, or MAP3K8 in several Spitz nevi) [2].

2. Intermediate melanocytic tumors may develop from benign nevi by acquiring an additional pathogenic mutation (BAP1 mutation in BAP1-inactivated nevus [3], CTNNB1 or APC in deep penetrating nevus [DPN] [4],
PRKAR1A or PRKCA in pigmented epithelioid melanocytoma [PEM] [5]).

3. Malignant melanoma develops after additional promoting mutations involving MAPK pathway genes (eg, NF1, $K I T, C C N D 1$ ), G1/S checkpoint regulation genes (eg, CDKN2A, CDK4, p53), chromatin modifier genes (SWI/ $S N F, B A P 1)$, and/or telomere regulation genes (TERT, SF3B1, EIF1AX) [6].

According to the WHO Working Group, intermediate melanocytic tumors are histopathologically defined as having increased cellularity and/or atypia if compared with a common nevus [1]. Thus, the molecular intermediate progression stage corresponds to a morphological intermediate and both are also mirrored by the intermediate biological behavior of melanocytomas, with their characteristically high incidence of nodal metastases coupled with a very low incidence of distant metastases [7].

In the progression model described above, nevi can be melanoma precursors because they are composed by partially transformed melanocytes. If so, common nevi do not 
exist at all because all of them harbor 1 potentially dangerous mutation; thus, a dichotomic histopathological approach (nevus vs melanoma) can no longer be applied as being too simplistic a view. However, the paradox according to which completely innocent nevi do not exist at all (because all of them harbor a potentially dangerous mutation) is obviously misleading because the estimated risk of malignant transformation of a nevus is roughly 1:33,000 [8]. Thus, the progression model from nevus to melanoma applies to a percentage of melanocytic tumors that is indeed minimal (even negligible, if one does not consider the potentially dramatic clinical consequences of such an unlikely event). Likewise, with distant metastases as the surrogate gold standard for malignancy, a progression of melanocytoma to conventional melanoma is highly unlikely.

In addition, the correlation between molecular and histopathological features is clearly imperfect to date, because melanocytomas themselves can show various degrees of histopathological atypia, and this "morphological spectrum within the spectrum" is incompletely mirrored by the molecular data available so far [9]. The consequence is that the mutations listed above for both benign and intermediate melanocytic tumors have no diagnostic or prognostic significance; they simply allow one to ascribe a given melanocytic tumor to a given subgroup (conventional, spitzoid, BAP1-deficient, dendritic cell [cellular blue nevus-like], DPN-like, PEM) [10].

Even the correlation between morphology and biological behavior of melanocytoma can be questioned, because several studies carried out on melanocytomas (all based on a low number of cases because of the relative rarity of such tumors and the need for long-term follow up [11]) have disclosed no clear-cut relationship between the qualitative and quantitative histopathological features of atypia and the clinical outcome. Notably, these studies were conceived with the goal of differ-

Table 1. Proposed List of Histopathological Criteria of Atypia for Prognostic Assessment of Melanocytomas

\begin{tabular}{|c|c|}
\hline Entity & $\begin{array}{l}\text { Proposed Criteria of Histopathological } \\
\text { Atypia }\end{array}$ \\
\hline $\begin{array}{l}\text { Melanocyoma } \\
\text { (applicable to all entities } \\
\text { listed below) }\end{array}$ & $\begin{array}{l}\text { - Large diameter }(>4 \mathrm{~mm} \text { ) } \\
\text { - Asymmetry/asymmetric involvement of the } \\
\text { epidermis } \\
\text { - Necrosis (single cell or en masse) } \\
\text { - Ulceration } \\
\text { - Mitoses }>2 / \mathrm{mm}^{2} \\
\text { - Cells within the lymph vessels }\end{array}$ \\
\hline Atypical Spitz tumor & $\begin{array}{l}\text { - Deep or marginal mitoses } \\
\text { - Solid sheets/nodular growth } \\
\text { - Brisk or heavy inflammatory infiltrate } \\
\text { - Deep extension (>2 mm in thickness) } \\
\text { - (Abundant) melanin in deep cells } \\
\text { - Confluent (nonrandom) nuclear } \\
\text { pleomorphism }\end{array}$ \\
\hline $\begin{array}{l}B A P 1 \text {-inactivated nevus/ } \\
\text { melanocytoma (BAP1- } \\
\text { inactivated melanocytic } \\
\text { atypical intradermal tumor) }\end{array}$ & $\begin{array}{l}\text { - Deep or marginal mitoses } \\
\text { - Confluent (not loose) sheets of cells } \\
\text { - Expansile growth } \\
\text { - Melanocytes with increased nucleo- } \\
\text { cytoplasmic ratio }\end{array}$ \\
\hline $\begin{array}{l}\text { Atypical cellular blue nevus/ } \\
\text { melanocytoma (atypical } \\
\text { dendritic cell tumor) }\end{array}$ & $\begin{array}{l}\text { - Irregularly oriented fascicles } \\
\text { - Areas of predominance of melanophages over } \\
\text { melanocytes } \\
\text { - Brisk or heavy inflammatory infiltrate } \\
\text { - Cytological atypia (prominent nucleoli; } \\
\text { dendritic cells with thick and irregular } \\
\text { processes) }\end{array}$ \\
\hline $\begin{array}{l}\text { Atypical deep penetrating } \\
\text { nevus/melanocytoma } \\
\text { (atypical deep penetrating } \\
\text { nevus-like tumor) }\end{array}$ & $\begin{array}{l}\text { - Quadrangular/nodular silhouette } \\
\text { - Lack of the context of a combined nevus } \\
\text { - Brisk or heavy inflammatory infiltrate }\end{array}$ \\
\hline $\begin{array}{l}\text { Pigmented epithelioid } \\
\text { melanocytoma }\end{array}$ & $\begin{array}{l}\text { - Deep or marginal mitoses } \\
\text { - Quadrangular/nodular silhouette } \\
\text { - Deep extension ( }>2 \mathrm{~mm} \text { in thickness) } \\
\text { - Confluent (nonrandom) nuclear } \\
\text { pleomorphism of the epithelioid cell } \\
\text { component } \\
\text { - Brisk or heavy inflammatory infiltrate } \\
\text { - Dendritic cells with thick and irregular } \\
\text { processes }\end{array}$ \\
\hline
\end{tabular}

entiating benign from malignant tumors with the use of different kinds of surrogate gold standard (interobserver agreement, nodal metastases, distant metastases, disease-related death [11,12]). However, the attempt at differentiating benign and malignant tumors within the intermediate category might be wrong: melanocytomas might repre- sent a unique broad category (with some morphomolecular subgroups) of tumors completely different from conventional melanocytic tumors, because they might not be morphobiologically intermediate, but morphobiologically peculiar. In fact, their rate of nodal metastases is much higher than that of conventional melanoma and their 
rate of distant metastases is extremely low (and not simply lower than that of melanoma of the same thickness); thus, they are peculiar because they probably stand as strongly lymphotropic (lowgrade) melanocytic malignancies [13].

If we consider melanocytomas as a unique broad category (with its subgroups), then it is not surprising that morphology alone cannot be predictive of the clinical outcome, because even in a cohort of conventional thick melanomas morphology alone cannot allow one to discriminate cases that will metastasize from cases that will not. In conventional melanoma, after making the diagnosis, there are some prognostic parameters (the most important being Breslow thickness and ulceration) that can help assess the risk of a melanoma to give metastasis; likewise, after making a diagnosis of melanocytoma, the histopathological assessment might be aimed at a prognostic evaluation. Thus, the best strategy might be listing the morphological features of atypia observed in any melanocytoma, thereby considering these features as prognostic factors and not as histopathological differential features between benign and malignant tumors. A list of these putative histopathological prognostic criteria for any category of melanocytoma is given in Table 1; and not secondary to these histopathological criteria, the clinical features of any melanocytoma-the patient's age; the location and the clinical features of the tumor-should be fully considered in order to assess the best management strategy.

\section{Conclusions}

The correlation between molecular and histopathological features of melanocytic tumors is still largely incomplete. From a practical point of view, however, only a very limited number of cases seen in clinical practice run the entire spectrum of molecular and biological progression of melanomagenesis; thus, the molecular progression model has a very limited clinical impact. Rather than intermediate stages in an unlikely path toward melanoma, melanocytomas are probably best regarded as morphobiologically peculiar melanocytic tumors, namely, strongly lymphotropic (lowgrade) melanocytic malignancies; their clinical management should be thus discussed case by case in a multidisciplinary setting by integrating the histopathological findings with the clinical data.

\section{References}

1. Bastian BC, de la Fouchardiere A, Elder DE, et al. Genomic landscape of melanoma. In: Elder DE, Massi D, Scolyer RA, Willemze R, eds. WHO Classification of Skin Tumours. 4th ed. Lyon, France: IARC; 2018:72-75.

2. Dimonitsas E, Liakea A, Sakellariou S, et al. An update on molecular alterations in melanocytic tumors with emphasis on spitzoid lesions. Ann Transl Med. 2018;6(12):249-265.

3. Wiesner T, Murali R, Fried I, et al. A distinct subset of atypical Spitz tumors is characterized by BRAF mutation and loss of BAP1 expression. Am J Surg Pathol. 2012;36(6):818-830.

4. Yeh I, Lang UE, Durieux E, et al. Combined activation of MAP kinase pathway and $\beta$-catenin signaling cause deep penetrating nevi. Nat Commun. 2017;8(1):644.
5. Cohen JN, Joseph NM, North JP, et al. Genomic analysis of pigmented epithelioid melanocytomas reveals recurrent alterations in PRKAR1A, and PRKCA genes. Am J Surg Pathol. 2017;41(10):1333-1346.

6. Papadodima O, Kontogianni G, Piroti G, Maglogianni I, Chatziioannou A. Genomics of cutaneous melanoma: focus on next-generation sequencing approaches and bioinformatics. J Transl Genet Genom. 2019;3:7. Available at: https:// jtggjournal.com/article/view/3027.

7. Zembovicz A, Scolyer RA. Nevus/melanocytoma/melanoma: an emerging paradigm for classification of melanocytic neoplasms? Arch Pathol Lab Med. 2011;135(3):300-306.

8. Tsao H, Bevona C, Goggins W, Quinn T. The transformation rate of moles (melanocytic nevi) into cutaneous melanoma: a population-based estimate. Arch Dermatol. 2003;139(3):282-288.

9. De la Fouchardière A, Caillot C, Jacquemus J, et al. $\beta$-Catenin nuclear expression discriminates deep penetrating nevi from other cutaneous melanocytic tumors. Virchows Arch. 2019;474(5):539-550.

10. Ferrara G, Improta G. Molecular diagnostics in melanocytic tumors: the pathologist's perspective. Adv Mol Diag. 2016;1(1). Available at: https://pdfs. semanticscholar.org/f146/4c 81 a 8 b $8 f$ 5922ef6dd699f4d0adc95bf7b06.pdf.

11. Ferrara G, De Vanna AC. Fluorescence in-situ hybridization for melanoma diagnosis: a review and a reappraisal. $A m$ J Dermatopathol. 2016;38(4):253-269.

12. Cerroni L, Barnhill R, Elder D, et al. Melanocytic tumors of uncertain malignant potential: results of a tutorial held at the XXIX Symposium of the International Society of Dermatopathology in Graz, October 2008. Am J Surg Pathol. 2010;34(3):314-326.

13. Lallas A, Krygidis A, Ferrara G, et al. Atypical Spitz tumours and sentinel lymph node biopsy: a systematic review. Lancet Oncol. 2014;15(4):e178-e183. 